\title{
ANALISIS KINERJA KEUANGAN PT. PLN (Persero) INDONESIA PERIODE 2011-2015
}

\author{
ITA PURNAMA SARI \\ HUSNAH \\ VITAYANTI FATTAH \\ Jurusan Manajemen, Fakultas Ekonomi, Universitas Tadulako \\ Email: itapurnama158@gmail.com
}

\begin{abstract}
The purpose of the research is to analyze the financial performance and financial health of PT. PLN (Persero) Indonesia in 2011- 2015 based on the Decree of the Ministry of State-Owned Enterprises No: KEP-100/MBU/2002 on company's health assessment on eight indicators: ROE, ROI, Current Ratio, Cash Ratio, Collection Period, Inventories, Total Assets Turn Over, and Total Ratio of Own Capital to Total Assets and Trend Analysis. The result shows that the financial performance of the liquidity ratio indicates that the company has not fully settled its current debt by using cash and guarantee the current debt with current assets. Profitability ratio shows the company's financial performance has not fully generate profit by using its own capital and company assets. Leverage ratio shows that the company is able to finance the assets with its own capital and at the ratio of activity indicates that the company has been optimal in using the receivables and inventory to generate revenue but the total rotation of assets not yet optimal used to generate income. Therefore, the health assessment on the financial aspects of PT. PLN (Persero) Indonesia in the period of 2011-2015is predicated less healthy.
\end{abstract}

Keywords: financial performance, financial ratios, and trend analysis

\begin{abstract}
Abstrak
Tujuan penelitian yakni menganalisis kinerja keuangan dan tingkat kesehatan keuangan PT. PLN (persero) Indonesia tahun 2011-015 berdasarkan Keputusan Menteri BUMN No: KEP100/MBU/2002 tentang penilaian kesehatan dengan menggunakan delapan indikator yaitu ROE, ROI, Current Ratio, Cash Ratio, Collection Period, Perputaran Persediaan, Total Asset Turn Over, dan Rasio Total Modal Sendiri terhadap Total Aktiva dan Analisis Trend. Hasil penelitian menunjukkan kinerja keuangan dari rasio likuiditas menunjukkan belum sepenuhnya perusahaan melunasi utang lancarnya dengan menggunakan kas dan menjamin utang lancar dengan aset lancar yang dimiliki.Rasio profitabilitas menunjukkan kinerja keuangan perusahaan belum sepenuhnya menghasilkan laba dengan mengunakan modal sendiri dan aktiva perusahaan. Pada rasio leverage menunjukkan bahwa perusahaan mampu membiayai aset dengan modal sendiri dan pada rasio aktivitas menunjukkan bahwa perusahaan sudah optimal dalam menggunakan piutang dan persediaan untuk menghasilkan pendapatan namun pada perputaran total aset belum optimal digunakan untuk menghasilkan pendapatan. Oleh karena itu, untuk penilaian kesehatan pada aspek keuangan PT. PLN (persero) Indonesia periode 2011-2015 mendapatkan predikat kurang sehat.
\end{abstract}

Kata kunci: kinerja keuangan, rasio keuangan, analisis trend

\section{PENDAHULUAN}

Semakin berkembangnya suatu negara sehingga memberikan dampak pada perkembangan teknologi di Indonesia.Sehingga dalam kehidupan sehari-hari masyarakat banyak menggunakan listrik untuk memenuhi kebutuhan mereka.Oleh sebab itu PT. PLN (persero) membantu negara dalam menyediakan energi listrik untuk penerangan rumah-rumah masyarakat yang berada di pelosok Indonesia, khususnya lagi membantu pelaku bisnis dan usaha rumah tangga dalam mengembangkan usahanya.

Sesuai akta nomor 169 tanggal 30 juli 1994 yang menyatakan bahwa status PLN dari perusahaan umum menjadi perusahaan perseroan (persero) dan pada tahun 2009, sesuai UU No. 30 tahun 2009 PLN tidak lagi sebagai kuasa usaha ketenagalistrikan (PKUK) dalam menyediakan listrik untuk kepentingan umum. PT. PLN (persero) merupakan salah satu badan usaha milik negara (BUMN), BUMN merupakan badan usaha yang seluruh atau sebagian besar modalnya dimiliki oleh negara 
melalui penyertaan secara langsung yang berasal dari kekayaan negara yang dipisahkan. Bentuk perusahaan yang dimaksud dalam BUMN diantaranya: persero yang berbentuk perseroan terbatas yang modalnya terbagi dalam saham yang seluruh atau paling sedikit 51\% (lima puluh satu persen) sahamnnya dimiliki oleh Negara Republik Indonesia yang tujuan utamanya memperoleh keuntungan.

Menilai kondisi kinerja keuangan perusahaan, maka dapat menggunakan analisis rasio keuangan yang terdiri dari Rasio Likuiditas digunakan untuk mengukur seberapa besar kemampuan perusahaan dalam memenuhi kewajiban jangka pendeknya. Rasio Leverage yaitu rasio yang mengukur seberapa banyak perusahaan menggunakan dana dari hutang (pinjaman). Rasio profitabilias atau rentabilitas yaitu rasio yang menunjukkan kemampuan perusahaan untuk memperoleh keuntungan dari penggunaan modalnya.Rasio Aktivitas atau sering juga dikenal sebagai Rasio Efisiensi yaitu rasio yang mengukur efisiensi perusahaan dalam menggunakan aset-asetnya.

Kinerja keuangan suatu perusahaan akan memberikan kontribusi pada pemilik perusahaan, baik tidaknya kinerja perusahaan akan memberikan dampak pada pemilik perusahaan, sepertihalnya PT. PLN (persero) yang memberikan kontribusi kepada pendapatan negara dan berpengaruh pada pendapatan ekonomi Indonesia. PT. PLN (Persero) merupakan perusahaan monopoli yang bergerak dibidang kelistrikan, sebagai perusahaan monopoli PT. PLN (Persero) memiliki aset, hutang, laba perusahaan dan rasio pertumbuhan tersebut dapat dilihat pada tabel berikut:

Tabel 1

Ringkasan Laporan Keuangan PT.PLN (persero) INDONESIA

(Disajikan dalam jutaan Rupiah)

\begin{tabular}{|l|l|l|l|l|l|l|}
\hline Thn. & \multicolumn{1}{|c|}{ Aktiva } & $\mathbf{( \% )}$ & Hutang & $\mathbf{( \% )}$ & Laba/Rugi & $\mathbf{( \% )}$ \\
\hline $\mathbf{2 0 1 1}$ & $426,518,863$ & $\mathbf{1 5 , 5}$ & $271,169,696$ & $\mathbf{2 3 , 5}$ & $7,193,626$ & $\mathbf{- 2 8 , 7}$ \\
\hline $\mathbf{2 0 1 2}$ & $540,705,764$ & $\mathbf{2 6 , 7}$ & $390,106,094$ & $\mathbf{4 3 , 9}$ & $3,205,524$ & $\mathbf{- 5 5 , 4}$ \\
\hline $\mathbf{2 0 1 3}$ & $595,877,391$ & $\mathbf{1 0 , 2}$ & $462,645,611$ & $\mathbf{1 8 , 6}$ & $(29,567,461)$ & $\mathbf{- 8 2 2}$ \\
\hline $\mathbf{2 0 1 4}$ & $603,659,191$ & $\mathbf{1 , 3 1}$ & $438,987,965$ & $\mathbf{- 5 , 1 1}$ & $11,741,610$ & $\mathbf{- 6 0 , 2}$ \\
\hline $\mathbf{2 0 1 5}$ & $1,227,355,512$ & $\mathbf{1 0 3 , 3}$ & $379,136,44$ & $\mathbf{- 1 3 , 6}$ & $15,585,238$ & $\mathbf{3 2 , 7}$ \\
\hline
\end{tabular}

Sumber : laporan keuangan PT. PLN (persero) (Desember, 2011-2015)

Berdasarkan tabel 1 dapat dilihat bahwa pada rasio pertumbuhan aktiva dari tahun 2011-2015 bergerak secara fluktuatif serta pada rasio pertumbuhan hutang juga bergerak secara fluktuatif dari tahun 2011-2015 tetapi tidak diikuti pada rasio pertumbuhan laba yang mengalami kerugian pada tahun 2013 dan perolehan laba pada tahun 2011-2014 dengan jumlah persentase minus atau dibawah nol yang berarti bahwa pada tahun 2011-2014 PT. PLN (Persero) berada pada kondisi tidak mampu untuk menghasilkan laba. Adanya fenomena dari kondisi keuangan PT. PLN (persero) dimana aktiva dan hutang mengalami peningkatan tetapi tidak diikuti laba perusahaan sehinggga berdampak pada kondisi kinerja keuangan PT. PLN (persero). PT. PLN merupakan Badan Usaha Milik Negara (BUMN) dimana untuk menilai kinerja keuangannya mengunakan peraturan yang sudah ditetapkan menteri BUMN, yang termuat dalam surat Keputusan Menteri BUMN Nomor : KEP-100/MBU/2002.

Melihat fenomena dari laporan keuangan pada PT. PLN (persero), maka penulis tertarik melakukan penelitian berjudul "Analisis Kinerja Keuangan pada PT. PLN (persero) INDONESIAberdasarkan Keputusan Menteri BUMN Nomor: KEP-100/MBU/2002”. Berdasarkan latar belakang di atas, maka rumusan masalah dalam penelitian ini adalah sebagai berikut:

1. Bagaimana kinerja keuangan PT. PLN (persero) INDONESIA berdasarkan Rasio Likuiditas menurut Keputusan Menteri Badan Usaha Milik Negara Nomor : Kep-100/MBU/2002?

2. Bagaimana kinerja keuangan PT. PLN (persero) INDONESIA berdasarkan Rasio Leverage menurut Keputusan Menteri Badan Usaha Milik Negara Nomor : Kep-100/MBU/2002?

3. Bagaimana kinerja keuangan PT. PLN (persero) INDONESIA berdasarkan Rasio Profitabilitas menurut Keputusan Menteri Badan Usaha Milik Negara Nomor : Kep-100/MBU/2002?

4. Bagaimana kinerja keuangan PT. PLN (persero) INDONESIA berdasarkan Rasio Aktivitas menurut Keputusan Menteri Badan Usaha Milik Negara Nomor : Kep-100/MBU/2002?

\section{KAJIAN LITERATURE DAN PENGEMBANGAN HIPOTESIS}


Menurut Werner R. Murhadi (2013) Laporan keuangan merupakan bahasa bisnis, laporan keuangan berisi informasi mengenai kondisi keuangan perusahaan kepada pihak pengguna dan memahami laporan keuangan suatu perusahaan, maka berbagai pihak yang berkepentingan dapat melihat kondisi kesehatan keuangan suatu perusahaan.Sedangkan, Menurut Irham Fahmi (2014:22) laporan keuangan merupakan suatu informasi yang menggambarkan kondisi suatu perusahaan, dimana selanjutnya itu akan menjadi suatu informasi yang menggambarkan tentang kinerja suatu perusahaan.

Menurut Kasmir (2010:93) rasio keuangan merupakan kegiatan membandingkan angka-angka yang ada dalam laporan keuangan dengan cara membagi satu angka dengan angka lainnya. Pembanding dapat dilakukan antara satu komponen dengan komponen dalam satu laporan keuangan atau antara komponen yang ada di antara laporan keuangan, Kemudian angka yang dibandingkan dapat berupa angka-angka dalam satu periode maupun beberapa periode.Laporan keuangan adalah media yang dapat di pakai untuk meneliti kondisi kesehatan perusahaan yang terdiri dari neraca, perhitungan laba rugi, ikhtisar laba yang ditahan, dan laporan posisi keuangan. laporan keuangan merupakan sarana utama membuat laporan informasi keuangan kepada orang-orang dalam perusahaan (manajemen dan para karyawan) dan kepada masyarakat diluar perusahaan (bank, pemasok, investor dan lain-lain).

Berikut Jenis-Jenis Rasio Keuangan:

1. Rasio Likuiditas

a. current ratio(Rasio Lancar)

b. Rasio kas atau cash ratio

2. Rasio leverage (solvabilitas)

a. Debt To Total Assets

b. Debt To Equity Ratio

c. Times Interest Earned

d. Fixed Charge Coverage

e. Times Interest Earned

3. Rasio Aktivitas (Activity Ratio)

a. Inventory Turnover (Perputaran Persediaan)

b. Rata-Rata Pengumpulan Piutang

c. Fixed Asset Turnover (Perputaran Aktiva Tetap)

d. Total Turn Over (Perputaran Total Aset)

4. Profitabilitas

a. Gross Profit Margin

b. Net profit Margin

c. Total Turn Over (Perputaran Total Aset)

Menurut Fidhayatin, (2012:205) dalam Erlina Yutikawati,( 2013). Kinerja perusahaan dapat dijadikan sebagai pedoman dalam mengukur keberhasilan suatu perusahaan. Kinerja perusahaan pengukuran atas prestasi perusahaan yang timbul akibat proses pengambilan keputusan manajemen, karena memiliki hubungan efektifitas pemanfaatan modal, efisiensi dan rentabilitas dari kegiatan kinerja. Kinerja keuangan yang dapat dicapai oleh perusahaan dalam satu periode tertentu merupakan gambaran sehat atau tidaknya suatu perusahaan. Selain dapat memberikan laba bagi para pemiliik modal atau investor, perusahaan yang sehat juga dapat menunjukkan kemampuan dalam membayar hutang dengan tepat waktu. Menurut Irham Fahmi (2014:2) kinerja keuangan adalah suatu analisis yang dilakukan untuk melihat sejauh mana suatu perusahaan telah melaksanakan dengan menggunakan aturan-aturan pelaksanaan keuangan secara baik dan benar.

Analisis kinerja keuangan dilakukan untuk mengetahui bagaimana pelaksanaan operasional dan kesehatan usaha perusahaan, untuk melakukan penilaian kesehatan usaha pada perusahaan BUMN telah ditentukan oleh pemerintah yang tertuang dalam keputusan mentri BUMN Nomor Kep.100/MBU/2002 yang mengatur tentang penilaian tingkat kesehatan perusahaan BUMN dan menggunakan analisis tren.Penilaian tingkat kesehatan BUMN dapat diukur dari beberapa indikator yang meliputi : imbalan kepada pemegang saham $(R O E)$, imbalan investasi (ROI), rasio kas, rasio lancar, collection period, perputaran persediaan, perputaran total aset dan rasio modal sendiri terhadap aktiva. (sumber: Keputusan Mentri BUMN Nomor Kep. 100/MBU/2002).

\section{METODE PENELITIAN}


Jenis Penelitian ini menggunakan metode analisis kuantitatif deskriptif.Jenis data dalam penelitian ini adalah data kuantitatif.Sumber data yang digunakan dalam penelitian ini adalah data sekunder.Metode Pengumpulan Data dalam penelitian ini dikumpulkan melalui dua tahapan, yakni Studi kepustakaan dan dokumentasi perusahaan. Variabel yang digunakan dalam penelitian ini adalah Rasio Likuiditas, Rasio Leverage, Rasio Aktivitas, dan Rasio Profitabilitas.

\section{Rasio Likuiditas}

a. Rumus current ratio(Rasio Lancar)

b. Rumus Rasio kas atau cash ratio

\section{Rasio leverage (solvabilitas)}

a. Rumus Debt To Total Assets adalah

b. Rumus Debt To Equity Ratio adalah

c. Rumus Times Interest Earned adalah

d. Rumus Fixed Charge Coverage adalah

e. Rumus Times Interest Earnedadalah

\section{Rasio Aktivitas (Activity Ratio)}

a. Inventory Turnover (Perputaran Persediaan)

b. Rata-Rata Pengumpulan Piutang

c. Fixed Asset Turnover (Perputaran Aktiva Tetap)

d. Total Turn Over (Perputaran Total Aset)

\section{Rasio Profitabilitas}

a. Gross Profit Margin

b. Net profit Margin

c. Return On Investment (ROI) 


\section{d. Total Turn Over (Perputaran Total Aset)}

Metode analisis yang digunakan adalah metode analisis rasio keuangan yang mengacu pada delapan indikator, sesuai tata cara penilaian kinerja keuangan BUMN untuk kategori non jasa keuangan yang bergerak dibidang infrastuktur pada aspek keuangan berdasarkan Keputusan Menteri BUMN No. KEP-100/MBU/2002 dan menggunakan analisis tren.

Tabel 2 Daftar Indikator dan Bobot

\begin{tabular}{|c|l|c|}
\hline No & \multicolumn{1}{|c|}{ Indikator } & Bobot \\
\hline 1 & ImbalanKepadaPemegangSaham (ROE) & 15 \\
\hline 2 & Imbalan Investasi (ROI) & 10 \\
\hline 3 & RasioKas & 3 \\
\hline 4 & RasioLancar & 4 \\
\hline 5 & Colection Period & 4 \\
\hline 6 & Perputaran persediaan & 4 \\
\hline 7 & Perputaran total asset & 4 \\
\hline 8 & Rasio modal sendiri terhadap total aktiva & 6 \\
\hline & \multicolumn{2}{|c|}{ Total Bobot } \\
\hline
\end{tabular}

Adapun rincian masing-masing indikator adalah sebagai berikut:

a. Imbalan Kepada Pemegang Saham/Return On Equity (ROE)

b. Imbalan Investasi/ Return On Investment (ROI)

c. Rasio Kas/ Cash Ratio

d. Rasio Lancar/Current Ratio

e. Collection Period (CP) / perputaran piutang

f. Perputaran Persediaan (PP)

g. Perputaran Total Asset/ Total Asset Turn Over (TATO)

h. Total Modal Sendiri Terhadap Total Asset (TMS terhadap TA)

\section{HASIL DAN PEMBAHASAN}

\section{Tabel 3}


Hasil Analisis Rasio Keuangan PT. PLN (persero) INDONESIA Periode 2011-2015 Berdasarkan Surat Keputusan Menteri BUMN Nomor: KEP-100/MBU/2002

\begin{tabular}{|l|l|l|l|l|l|}
\hline \multicolumn{1}{|c|}{ Keterangan } & \multicolumn{1}{|c|}{$\mathbf{2 0 1 1}$} & \multicolumn{1}{c|}{$\mathbf{2 0 1 2}$} & \multicolumn{1}{c|}{$\mathbf{2 0 1 3}$} & \multicolumn{1}{c|}{$\mathbf{2 0 1 4}$} & \multicolumn{1}{c|}{$\mathbf{2 0 1 5}$} \\
\hline ROE & $4,63 \%$ & $2,12 \%$ & $-19,9 \%$ & $7,13 \%$ & $1,83 \%$ \\
\hline ROI & $6,63 \%$ & $4,68 \%$ & $10,25 \%$ & $6,54 \%$ & $1,99 \%$ \\
\hline Cash ratio & $36,11 \%$ & $30,85 \%$ & $29,01 \%$ & $31,07 \%$ & $20,24 \%$ \\
\hline Current ratio & $92,58 \%$ & $92,00 \%$ & $96,06 \%$ & $97,56 \%$ & $67,81 \%$ \\
\hline Collection periods & 6,14 hari & 6,04 hari & 22,25 hari & 24,30 hari & 33,30 hari \\
\hline Perputaran persediaan & 27,46 hari & 26,25 hari & 16,08 hari & 14,47 hari & 19,17 hari \\
\hline Perputaran Total Aset & $61,28 \%$ & $46,62 \%$ & $30,49 \%$ & $42,63 \%$ & $15,21 \%$ \\
\hline TMS terhadp TA & $36,42 \%$ & $27,85 \%$ & $22,35 \%$ & $27,27 \%$ & $69,11 \%$ \\
\hline
\end{tabular}

Sumber: data diolah

Tabel 4

Penilaian Aspek Keuangan PT. PLN (Persero) INDONESIA

Berdasarkan Surat Keputusan Menteri BUMN No: KEP-100/MBU/2002

\begin{tabular}{|c|c|c|c|c|c|c|c|}
\hline & & \multicolumn{5}{|c|}{ Skor } & \\
\cline { 3 - 7 } No & Indikator & $\mathbf{2 0 1 1}$ & $\mathbf{2 0 1 2}$ & $\mathbf{2 0 1 3}$ & $\mathbf{2 0 1 4}$ & $\mathbf{2 0 1 5}$ & Bobot \\
\hline 1 & Return On Equity & 5 & 4 & 0 & 9 & 3 & 15 \\
\hline 2 & Return On Invesment & 3.5 & 3 & 6 & 3 & 2.5 & 10 \\
\hline 3 & Cash Ratio & 3 & 2.5 & 2.5 & 2.5 & 2 & 3 \\
\hline 4 & Current Ratio & 1 & 1 & 1.5 & 1.5 & 0 & 4 \\
\hline 5 & Collection Periods & 4 & 4 & 4 & 4 & 4 & 4 \\
\hline 6 & Perputaran Persediaan & 4 & 4 & 4 & 4 & 4 & 4 \\
\hline 7 & Perputaran total aset & 2 & 1.5 & 1 & 1.5 & 0.5 & 4 \\
\hline 8 & TMS terhadap TA & 6 & 4 & 4 & 4 & 4.5 & 6 \\
\hline & Total & 28.5 & 24 & 23 & 29.5 & 20.5 & 50 \\
\hline
\end{tabular}

Sumber: data diolah

Tabel 5

Penilaian Tingkat Kesehatan PT. PLN (persero) INDONEISIA

berdasarkan Surat Kepetusan Menteri BUMN Nomor: KEP-100/MBU/2002

\begin{tabular}{|c|c|c|c|c|c|c|}
\hline \multirow[t]{2}{*}{ Tahun } & $\begin{array}{l}\text { Total } \\
\text { Skor }\end{array}$ & Bobot & Total bobot & \multicolumn{2}{|c|}{ Nilai } & \multirow[t]{2}{*}{ Kategori } \\
\hline & (1) & (2) & $(1):(2) \times 100 \%$ & & & \\
\hline 2011 & 28.5 & \multirow{5}{*}{50} & 57 & TS & $\leq 65$ & BBB/ KURANG SEHAT \\
\hline 2012 & 24 & & 48 & TS & $\leq 50$ & BB/ KURANG SEHAT \\
\hline 2013 & 23 & & 46 & TS & $\leq 50$ & BB/ KURANG SEHAT \\
\hline 2014 & 29.5 & & 59 & TS & $\leq 65$ & BBB/ KURANG SEHAT \\
\hline 2015 & 20.5 & & 41 & TS & $\leq 50$ & BB/KURANG SEHAT \\
\hline
\end{tabular}

Sumber: data diolah 


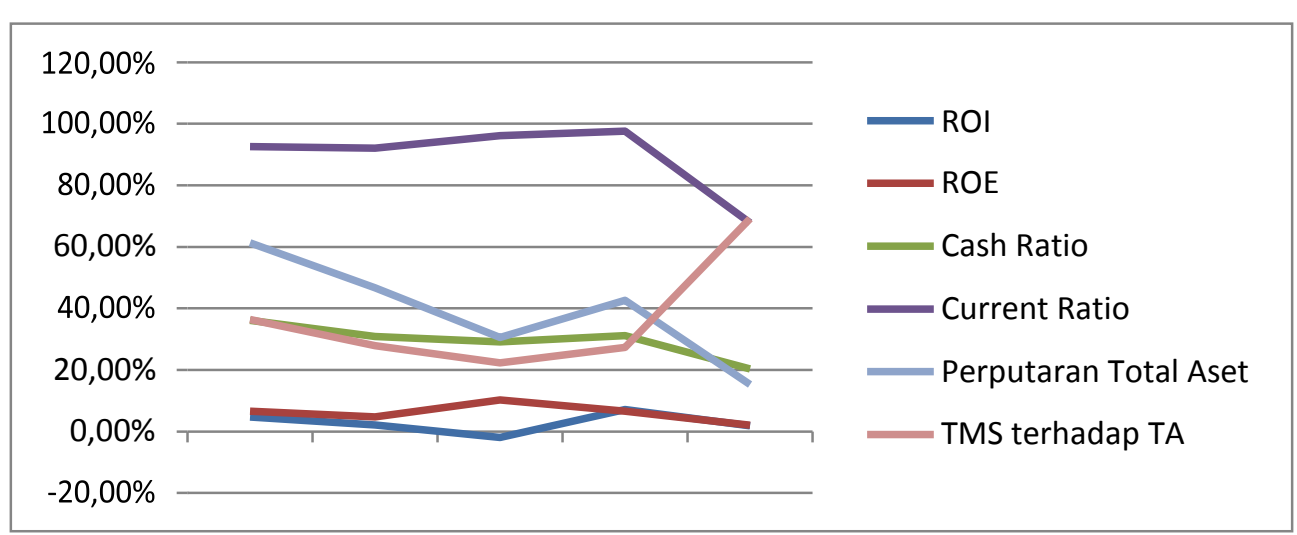

Gambar 1 Analisis Trend (dalam persen)

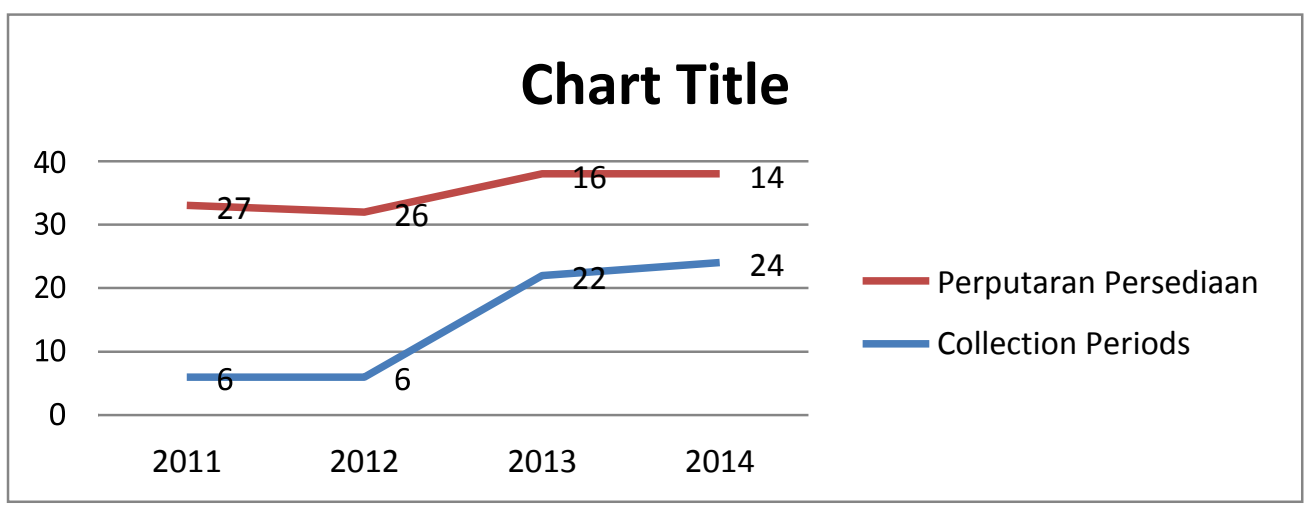

Gambar 2 Analisis Trend (dalam hari)

\section{Rasio Profitabilitas}

- Hasil ROE pada tahun 2011-2015 mengalami penurunan dengan skor yang diperoleh dibawa bobot nilai maksimal, hal ini menunjukkan bahwa perusahaan masih kurang baik dalam tingkat pengembalian saham kepada para investor dan hal ini juga terlihat pada grafik analisis tren.

- Hasil ROI dimana pada tahun 2011-2015 yang mengalami penurunan dengan skor dibawah bobot maksimal, hal ini dikarenakan masih banyak proyek yang belum selesai dikerjakan, dan grafik analisis tren yang berfluktuatif cenderung menurun artinya bahwa kinerja keuangan perusahaan belum sepenuhnya bisa mengahasilkan laba dengan mengunakan modal sendiri dan seluruh aktiva perusahaan.

Rasio Likuiditas

- Hasil dari cash ratio yang tinggi dan skor yang didapatkan hampir mendekati bobot maksimal yang menunjukkan bahwa jumlah uang tunai yang dimilikki semakin besar dan dalam membayar kewajiban jangka pendek tidak mengalami kesulitan.

- Tetapi berbeda dengan current ratio dimana hasilnya rendah dan skor yang tidak mencapai bobot maksimal yang menunjukkan bahwa ketidakmampuan PT. PLN (persero) INDONESIA menjamin seluruh utang lancarnya dengan semua aset lancarnya.

Rasio Aktivitas

- Hasil dari perputaran piutang dan perputaran persediaan yang memperoleh skor yang sama dan mencapai bobot maksimal artinya bahwa perusahaan dalam memanfaatkan sumber daya yang ada sudah efektif.

- Hasil dari perputaran total aset pada tahun 2011-2015 yang memperoleh skor yang tidak mencapai bobot berdasarkan keputusan Menteri BUMN nomor : KEP-100/MBU/2002 artinya bahwa perusahaan belum optimal dalam menggunakan asetnya untuk menghasilkan pendapatan. Hal ini terlihat pada grafik tren analisis perputaran piutang dan grafik tren perputaran persediaan yang meningkat, Artinya bahwa perusahaan sudah optimal dalam mengelola perputaran persediaan dan tidak ada penumpukan persediaan dan tidak ada piutang yang tidak tertagih. Sedangkan grafik tren 
perputaran total aset berfluktuatif menurun artinya bahwa PT. PLN (persero) INDONESIA belum efkif menggunakan asetnya.

Rasio Leverage

- Hasil dari total modal sendiri terhadap total aktiva dengan perolehan skor yang mendekati bobot pada tahun 2011-2015 artinya bahwa perusahaan mampu untuk membiayai aset dengan modal sendiri, hal ini terlihat pada modal perusahaan yang meningkat setiap tahunnya dan sebanding dengan peningkatan asetnya setiap tahun, ini juga terlihat pada grafik tren yang meningkat.

\section{KESIMPULAN DAN SARAN}

\section{Kesimpulan}

1. Rasio Profitabilitaspada tahun 2011-2015pada indikator ROE (Return On Equity) yang berfluktuatif dan ROI (Return On Invesment) yang berfluktuatif, hal ini menunjukkan bahwa PT. PLN (persero) INDONESIA belum sepenuhnya menggunakan aktiva dan modalnya untuk menghasilkan keuntungan.

2. Rasio likuiditas pada tahun 2011-2015 pada Rasio Kasyang mengalami peningkatan setiap tahunnya sedangkan pada Rasio Lancar yang berfluktuatif menurun, artinya bahwa PT. PLN (persero) INDONESIA memiliki kemampuan untuk menjamin utang lancarnya dengan kas dan setara kas tetapi aset lancar yang dimiliki perusahaan tidak mampu untuk menjamin utang lancar.

3. Rasio Aktivitas pada tahun 2011-2015 menunjukkan bahwa PT. PLN (persero) INDONESIA mampu menggunakan aset-asetnya secara efisien ini terlihat pada Perputaran Piutang, Perputaran Persedian sedangkan Perputaran Total Aset yang berfluktuasi dalam artian bahwa PT. PLN (persero) INDONESIA belum maksimal menggunakan semua asetnya untuk menghasilkan pendapatan.

4. Rasio leverage pada tahun 2012-2015 mengalami peningkatan pada tahun 2011-2015 hal ini menunjukkan bahwa PT. PLN (persero) INDONESIAmemiliki modal sendiri untuk membiayai asetnya.

\section{Saran}

1. Sebaiknya PT. PLN (persero) INDONESIA melakukan evaluasi pada indikator Rasio Profitabilitas, Rasio Likuiditas dan Rasio Leverage yang tidak menunjukkan peningkatan dan meningkatkan kinerja.

2. Bagi penelitian selanjutnya diharapkan lebih meningkatkan penelitian dengan melakukan penelitian pada perusahaan BUMN lainnya dan menggunakan alternatif metode pengukuran kinerja keuangan yang lain.

\section{REFERENSI}

Fahmi, Irham. (2014). Analisis Kinerja Keuangan: Panduan bagi Akademisi, Manajer, dan Investor untuk Menilai dan Menganalisis Bisnis dari Aspek Keuangan. Cetakan kesatu, Alfabeta, Bandung.

Kasmir, (2010). Pengantar Manajemen Keuangan.Cetakan pertama, Kencana Prenada Media Group, Jakarta.

Murhadi, Werner. R. (2013). Analisis Laporan keuangan : Proyeksi dan Valuasi Saham. Salemba empat. Jakarta.

Yutikawati, Erlina. (2013). Analisis Laporan Keuangan Untuk Menilai Kinera keuangan pada PT. RakabuSejahtra di Sragen. Fakultas Ekonomi dan Bisnis, Universitas Muhammadiyah Surakarta.

Keputusan Mentri BUMN Nomor: KEP - 100/MBU/2002

http://www.pln.co.id 